\title{
Identification of a lineage of multipotent hematopoietic progenitors
}

\author{
Sean J. Morrison*, Antoni M. Wandycz, Houman D. Hemmati, Douglas E. Wright and Irving L. Weissman \\ Departments of Pathology and Developmental Biology, Stanford University, Stanford, California, 94305, USA \\ ${ }^{*}$ Current address and author for correspondence: Division of Biology 216-76, California Institute of Technology, Pasadena, California, 91125, USA \\ (e-mail: MorrisonS@starbase1.caltech.edu)
}

\section{SUMMARY}

All multipotent hematopoietic progenitors in C57BLThy-1.1 bone marrow are divided among three subpopulations of $\mathrm{Thy}-1.1^{10} \mathrm{Sca}-1^{+} \mathrm{Lin}^{-/ 10} \mathrm{c}-\mathrm{kit}^{+}$cells: long-term reconstituting $\mathrm{Mac}^{-} \mathrm{1}^{-} \mathrm{CD4}^{-} \mathrm{c}-\mathrm{kit}^{+}$cells and transiently reconstituting Mac- $1^{10} \mathrm{CD}^{-}$or $\mathrm{Mac}-1^{\mathrm{lo}} \mathrm{CD} 4^{\text {lo }}$ cells. This study shows that the same populations, with similar functional activities, exist in mice whose hematopoietic systems were reconstituted by hematopoietic stem cells after lethal irradiation. We demonstrate that these populations form a lineage of multipotent progenitors from long-term self-renewing stem cells to the most mature multipotent progenitor population. In reconstituted mice,

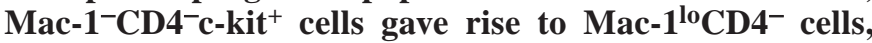

which gave rise to $\mathrm{Mac}-1^{\mathrm{lo}} \mathrm{CD} 4{ }^{\text {lo }}$ cells. $\mathrm{Mac}-1^{-} \mathrm{CD}^{-} \mathrm{c}-\mathrm{kit}^{+}$ cells had long-term self-renewal potential, with each cell being capable of giving rise to more than $10^{4}$ functionally similar Mac-1-CD4-c-kit ${ }^{+}$cells. At least half of Mac$1^{10} \mathrm{CD4}^{-}$cells had transient self-renewal potential, detected in the spleen 7 days after reconstitution. Mac${ }^{10} \mathrm{CD}^{\text {lo }}$ cells did not have detectable self-renewal potential. The identification of a lineage of multipotent progenitors provides an important tool for identifying genes that regulate self-renewal and lineage commitment.

Key words: hematopoietic stem cell, lineage, transplantation, selfrenewal, bone marrow, blood, stem cell

\section{INTRODUCTION}

The bone marrow multipotent progenitor pool must satisfy the conflicting demands of life-long self-renewal as well as the need to give rise to large numbers of mature blood cells each day. Two models of hematopoietic stem cell (HSC) differentiation and self-renewal have been advanced based on the reconstituting activity of whole bone marrow: clonal succession (Kay, 1965) and the generation age hypothesis (Rosendaal et al., 1979). Both models postulated the existence of different classes of HSC including rare quiescent cells that maintain the progenitor pool over the long-term and larger numbers of cycling multipotent progenitors, with limited self-renewal potential, that give rise to lineage committed progenitors (Kay, 1965; Hellman et al., 1978; Rosendaal et al., 1979). Micklem and Ogden (1976) predicted that bone marrow multipotent progenitors must be divided into a lineage of at least three distinct populations. They predicted that the most immature population would have long-term self-renewal potential, few cells in cycle and the ability to give rise to very large numbers of progeny. The intermediate population(s) would have less self-renewal potential, more cells in cycle and the ability to give rise to fewer progeny. The most mature multipotent progenitor population prior to lineage commitment was postulated to have little self-renewal potential and a high proportion of cells in cycle (Micklem and Ogden, 1976).

We have purified three populations of bone marrow multipotent hematopoietic progenitors with properties that are consistent with the hypothetical lineage of stem cells proposed in the models (Morrison and Weissman, 1994). The most primitive population is Thy- ${ }^{\text {lo }} \mathrm{Sca}-1^{+} \mathrm{Lin}^{-} \mathrm{Mac}-1^{-} \mathrm{CD} 4{ }^{-} \mathrm{c}-\mathrm{kit}{ }^{+}$ (referred to as Mac- $1^{-} \mathrm{CD} 4^{-} \mathrm{c}-\mathrm{kit}^{+}$) representing approximately $0.007 \%$ of bone marrow. $80 \%$ of single cells transplanted in vivo are multipotent and have long-term self-renewal potential. Only around $4 \%$ of cells are in $\mathrm{S} / \mathrm{G}_{2} / \mathrm{M}$ phases of the cell cycle at any time. Thy- $1^{\text {lo }} \mathrm{Sca}-1^{+} \mathrm{Lin}^{-} \mathrm{Mac}-1^{\mathrm{lo}} \mathrm{CD} 4{ }^{-}$cells (referred to as $\mathrm{Mac}-1^{\mathrm{lo}} \mathrm{CD}^{-}$) represent around $0.01 \%$ of bone marrow. Most cells in this population are transiently reconstituting multipotent progenitors and $7 \%$ of cells are in $\mathrm{S} / \mathrm{G}_{2} / \mathrm{M}$ phases on average. Thy- $1^{\text {lo }} \mathrm{Sca}-1^{+} \mathrm{Mac}-1^{10} \mathrm{CD} 4^{10}$ cells (referred to as Mac$1^{\mathrm{lo}} \mathrm{CD} 4{ }^{\mathrm{lo}}$ ) average $0.03 \%$ of bone marrow and $18 \%$ of cells are in $\mathrm{S} / \mathrm{G}_{2} / \mathrm{M}$ phases of the cell cycle. This population contains a mixture of transiently reconstituting multipotent progenitors and progenitors that only give rise to detectable B cells. These populations include all multipotent hematopoietic progenitors in C57BL-Thy-1.1 mice (Uchida and Weissman, 1992).

We hypothesized that the three Thy- $1^{\text {lo }} \mathrm{Sca}-1^{+} \mathrm{Lin}^{-/ \mathrm{lo}}$ subpopulations form a lineage in which Mac- $1^{-} \mathrm{CD} 4^{-} \mathrm{c}-\mathrm{kit}^{+}$cells give rise to $\mathrm{Mac}-1^{10} \mathrm{CD} 4^{-}$cells, which give rise to Mac$1^{10} \mathrm{CD} 4{ }^{10}$ cells. This paper describes the results of extensive analyses of reconstituted mice and secondary transfer experiments that tested this hypothesis.

\section{MATERIALS AND METHODS}

\section{Mouse strains}

C57BL/J (Ly5.1, Thy-1.2) and C57BL/Ka-Thy1.1 (Ly 5.2) mouse strains were bred and maintained on acidified water $(\mathrm{pH} 2.5)$ at the animal care facility at the Stanford University School of Medicine. 
Normal donors of multipotent progenitors were 6-10 weeks old. Irradiated recipient mice were 8 to 14 weeks old at the time of irradiation.

\section{Antibodies}

The antibodies used in immunofluorescence staining included 19XE5 (anti-Thy1.1), AL1-4A2 (anti-Ly5.2), A20.1 (anti-Ly5.1), 2B8 (anti-c-kit) and E13 (anti-Sca-1, Ly6A/E). Lineage marker antibodies included KT31.1 (anti-CD3), 53-7.3 (anti-CD5), 53-6.7 (antiCD8), Ter119 (anti-erythrocyte specific antigen), 6B2 (anti-B220) and 8C5 (anti-Gr-1). M1/70 (anti-Mac-1) and GK1.5 (anti-CD4) staining of hematopoietic populations were described separately from the lineage cocktail to distinguish long-term and transient progenitor populations.

\section{Bone marrow preparation and staining}

Marrow was flushed from the femurs and tibias of donor mice. Singlecell suspensions were prepared by drawing the bone marrow cells through a 25-gauge needle, then expelling them back through the needle and through a nylon mesh screen. Cells were suspended in Hanks' balanced salt solution (HBSS, without phenol red) (Applied Scientific, San Francisco, CA) containing 2\% calf serum.

For HSC purification, cells were incubated with a cocktail of unlabeled lineage marker antibodies including those specific for CD3, CD4, CD5, CD8, Gr-1, Ter119, B220 and Mac-1. All antibody incubations were for 20 minutes on ice, prior to diluting the cells and centrifuging through a calf serum cushion. The cells were incubated with PE-conjugated anti-rat antibody to visualize the lineage markers. The cells were then incubated with $19 \mathrm{XE}^{\mathrm{FITC}}$, E13 ${ }^{\text {bio }}$ and $2 \mathrm{~B} 8^{\mathrm{APC}}$. When donor-type HSC were sorted from reconstituted mice, A20.1 $1^{\mathrm{PE}}$ was included in the lineage cocktail to further discriminate recipient-type from donor-type progenitors (in addition to the Thy-1 difference). If a Mac- $1^{\text {lo }}$ population was to be sorted, then Mac-1 was not included in the lineage cocktail and M1/70 $\mathrm{APC}$ was used instead of $2 \mathrm{~B} 8^{\mathrm{APC}}$. Similarly, if Mac- $1^{10} \mathrm{CD} 4^{\text {lo }}$ cells were sorted then $\mathrm{CD} 44^{\mathrm{PE}}$ replaced the lineage cocktail. Sca- ${ }^{+}$cells were sometimes pre-enriched by positive selection using MACS ${ }^{\circledR}$ streptavidin-conjugated magnetic beads according to the manufacturer's instructions. The cells were resuspended in $0.5 \mu \mathrm{g} / \mathrm{ml}$ of propidium iodide (PI) prior to FACS analysis.

\section{Cell sorting and analyses}

Most analyses and all cell sorts were performed on a dual laser FACS ${ }^{\circledR}$ (Becton Dickinson, Mountain View, CA), modified as described (Parks and Herzenberg, 1984). Progenitors were usually purified by sorting and then resorting to obtain precise numbers of cells, which were essentially pure for the indicated surface marker phenotype. In the case of single cell clonogenic assays, the resort was performed in cloning mode in which single cells were deposited into methylcellulose medium in a 96-well plate or into stromal cell cultures in a 24-well plate.

\section{Functional analyses}

Long-term reconstitution of lethally irradiated mice, day 12 CFU-S, colony formation on AC-6 stroma and colony formation in methylcellulose were assayed as described previously (Morrison et al., 1996b).

\section{RESULTS}

\section{The isolation of multipotent progenitors from reconstituted mice}

We sought to determine whether the subpopulations of Thy$1^{\text {lo }} \mathrm{Sca}-1^{+} \mathrm{Lin}^{-/ l o}$ cells that contain all multipotent progenitors in normal C57BL-Thy-1.1 (Ly5.2) bone marrow also contain the multipotent progenitor activity in reconstituted mice. C57BL/J (Thy-1.2, Ly5.1) mice were lethally irradiated and reconstituted with $60 \mathrm{Mac}-1^{-} \mathrm{CD} 4{ }^{-} \mathrm{c}-\mathrm{kit}^{+}$cells from a C57BLThy-1.1 (Ly5.2) donor. On average 1 out of $10 \mathrm{Mac}-1^{-} \mathrm{CD}^{-}$ $\mathrm{c}-\mathrm{kit}^{+}$cells from normal marrow engrafts and gives rise to detectable progenitor activity upon intravenous injection (Morrison and Weissman, 1994). If 15\% of bone marrow is in the femurs and tibia (Smith and Clayton, 1970), the long bones of a mouse injected with $60 \mathrm{Mac}-1^{-} \mathrm{CD}^{-} \mathrm{c}-\mathrm{kit}^{+}$cells would be reconstituted on average by a single progenitor cell. 2-15 weeks later, Mac- $1^{-} \mathrm{CD}^{-}{ }^{-} \mathrm{c}-\mathrm{kit}^{+}, \mathrm{Mac}-{ }^{\mathrm{lo}} \mathrm{CD} 4^{-}$or Mac$1^{10} \mathrm{CD} 4{ }^{\text {lo }}$ cells were purified by fluorescence activated cell sorting (FACS) from the reconstituted mice. Donor-derived progenitors were distinguished from host-derived progenitors by selecting cells expressing Thy- 1.1 and by excluding Ly $5.1^{+}$ cells. Donor-type Mac- $1^{-} \mathrm{CD} 4{ }^{-} \mathrm{c}-\mathrm{kit}^{+}, \mathrm{Mac}-{ }^{\mathrm{lo}} \mathrm{CD}^{-}{ }^{-}$and Mac$1^{\mathrm{lo}} \mathrm{CD} 4^{\mathrm{lo}}$ cells were purified from the reconstituted recipients.

The purified cells were tested for progenitor activity in long-term reconstitution assays in which 15 to 100 cells from either population were competed against a radioprotective dose of 200,000 recipient-type whole bone marrow cells. When purified from normal bone marrow, only 10 cells from any of these populations consistently reconstituted 60 to $70 \%$ of recipients (Morrison and Weissman, 1994). At doses of 15 to 30 cells, the Mac- $1^{-} \mathrm{CD}^{-}{ }^{-} \mathrm{c}-\mathrm{kit}^{+}$population isolated from reconstituted mice exhibited detectable progenitor activity in only 1 out of 35 recipients. Nine of nine mice in one experiment and four of five mice in a second experiment were reconstituted by $15 \mathrm{Mac}-1^{-} \mathrm{CD} 4^{-} \mathrm{c}-\mathrm{kit}^{+}$cells purified from normal donors. This demonstrates that the difference in progenitor activity between $\mathrm{Mac}-1^{-} \mathrm{CD} 4{ }^{-} \mathrm{c}-\mathrm{kit}^{+}$cells purified from normal and reconstituted mice is highly significant $(P<0.001)$. At higher cell doses, long-term multilineage progenitor activity was readily observed from the Mac-1 ${ }^{-}$ $\mathrm{CD} 4^{-} \mathrm{c}-\mathrm{kit}^{+}$population purified from reconstituted mice. Fig. 1 shows the reconstitution profiles of nine mice competitively

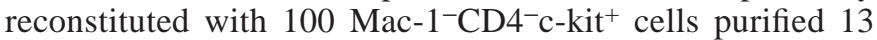
weeks after the reconstitution of primary recipients with Mac- $1^{-} \mathrm{CD} 4^{-} \mathrm{c}-\mathrm{kit}^{+}$cells from normal bone marrow. Of the individuals shown in the figure, five were long-term multilineage reconstituted (LTMR), three were transiently multilineage reconstituted (TMR) and one was reconstituted only by myeloid and B cells. Overall, of 30 mice competitively reconstituted by 50 to $100 \mathrm{Mac}-1^{-} \mathrm{CD}^{-}{ }^{-} \mathrm{c}-\mathrm{kit}^{+}$cells purified from reconstituted mice, ten were LTMR, seven were TMR, eight were reconstituted only in one or two lineages, and five mice were unreconstituted by donor-type cells. Thus Mac-1 ${ }^{-}$ $\mathrm{CD}^{-}{ }^{-} \mathrm{-}-\mathrm{kit}^{+}$cells purified from reconstituted mice exhibit progenitor activity in competitive reconstitution assays much less frequently than the same population from normal bone marrow. Although $\mathrm{Mac}-1^{-} \mathrm{CD} 4^{-} \mathrm{c}-\mathrm{kit}^{+}$cells from reconstituted mice are highly enriched for LTMR activity, they include a higher proportion of cells that exhibit transient progenitor activity than normal bone marrow $\mathrm{Mac}-1^{-} \mathrm{CD} 4^{-} \mathrm{c}-$ $\mathrm{kit}^{+}$cells.

Similar results were obtained from Mac- $1^{10} \mathrm{CD} 4^{-}$cells purified from reconstituted mice. Of mice injected with 15-25 cells, only 7 of 33 recipients became competitively reconstituted by donor-type cells (1 LTMR, 3 TMR, 3 oligopotent reconstitutions). However, 21 of 23 mice injected with $15 \mathrm{Mac}-1^{10} \mathrm{CD}^{-}$ cells purified from a normal donor became competitively recon- 
Fig. 1. Levels of donor cell reconstitution in irradiated mice reconstituted by Thy$1^{\text {loS }}{ }^{-1}{ }^{+}$Lin $^{-} \mathrm{Mac}^{-1}{ }^{-}$ $\mathrm{CD}^{-}{ }^{-} \mathrm{c}-\mathrm{kit}^{+}\left(\mathrm{Mac}-1^{-}\right.$ $\left.\mathrm{CD} 4^{-} \mathrm{c}-\mathrm{kit}^{+}\right)$cells purified from mice reconstituted by Mac- $1^{-} \mathrm{CD} 4^{-} \mathrm{c}-\mathrm{kit}^{+}$ cells from normal marrow 13 weeks previously. Fifteen secondary recipients received 100 donor-type Mac- $1^{-} \mathrm{CD} 4^{-} \mathrm{c}-\mathrm{kit}^{+}$cells plus 200,000 host-type whole bone marrow cells for radioprotection. Each line represents an individual mouse and the shaded area represents the range of background signals observed in negative control mice. Overall 14 mice were reconstituted by donortype cells including 5 that were long-term multilineage reconstituted (LTMR), 4 that were transiently multilineage reconstituted, 3 reconstituted only by $\mathrm{B}$ and T cells, 1 reconstituted only by donor-type B cells and 1 reconstituted only by myeloid and B cells. For purposes of clarity, the figure depicts the reconstitution profiles of 9 of these mice including 5 that were LTMR (open square, filled square, open circle, filled circle, $\mathrm{X}), 3$ that were transiently multilineage reconstituted (filled diamond, open triangle, filled triangle) and 1 reconstituted only by donor lymphoid cells (open diamonds).
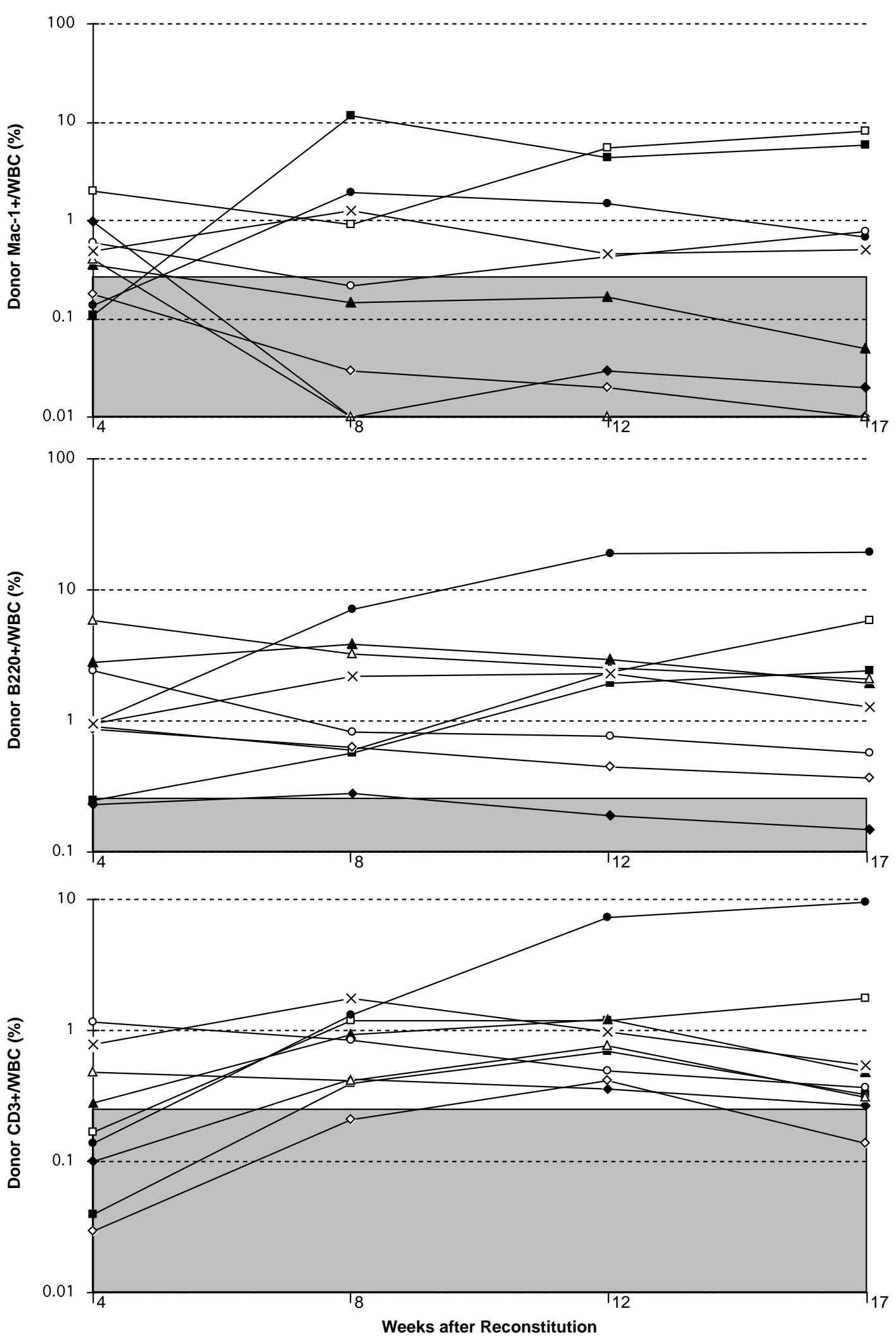

stituted, demonstrating that the difference in the reconstituting activity of $\mathrm{Mac}-1^{\mathrm{lo}} \mathrm{CD} 4-$ cells purified from normal and reconstituted donors is highly significant $(P<0.001)$. At higher cell doses, transient multipotent progenitor activity was readily observed from Mac- $1^{\text {lo }} \mathrm{CD} 4^{-}$cells purified from reconstituted mice. Fig. 2 shows the donor cell reconstitution profiles of five 
Fig. 2. Lethally irradiated mice were reconstituted by 60 Thy- $1^{\text {lo Sca }}-1^{+}$Lin $^{-}$

Mac- $1^{-} \mathrm{CD} 4^{-}$c-kit ${ }^{+}$cells.

15 weeks later Thy- $1^{\text {lo }}$ Sca$1^{+} \mathrm{Lin}^{-\mathrm{Mac}-} \mathrm{1}^{\mathrm{lo}} \mathrm{CD} 4^{-}$

(Mac- $1^{10} \mathrm{CD}^{-}{ }^{-}$) cells were purified by FACS from the bone marrow of these primary recipients and transferred to lethally irradiated secondary recipients. Five secondary recipients received 75 donor-type Mac- $1^{\mathrm{lo}} \mathrm{CD} 4$ cells plus 200,000 hosttype whole bone marrow cells for radioprotection. Each line represents an individual mouse and the shaded area represents the range of background signals observed in negative control mice. Four secondary recipients were transiently multilineage reconstituted by donor-type cells (open square, filled square, open diamond, filled triangle) and one mouse was reconstituted by donortype $\mathrm{B}$ and $\mathrm{T}$ cells (filled diamonds).
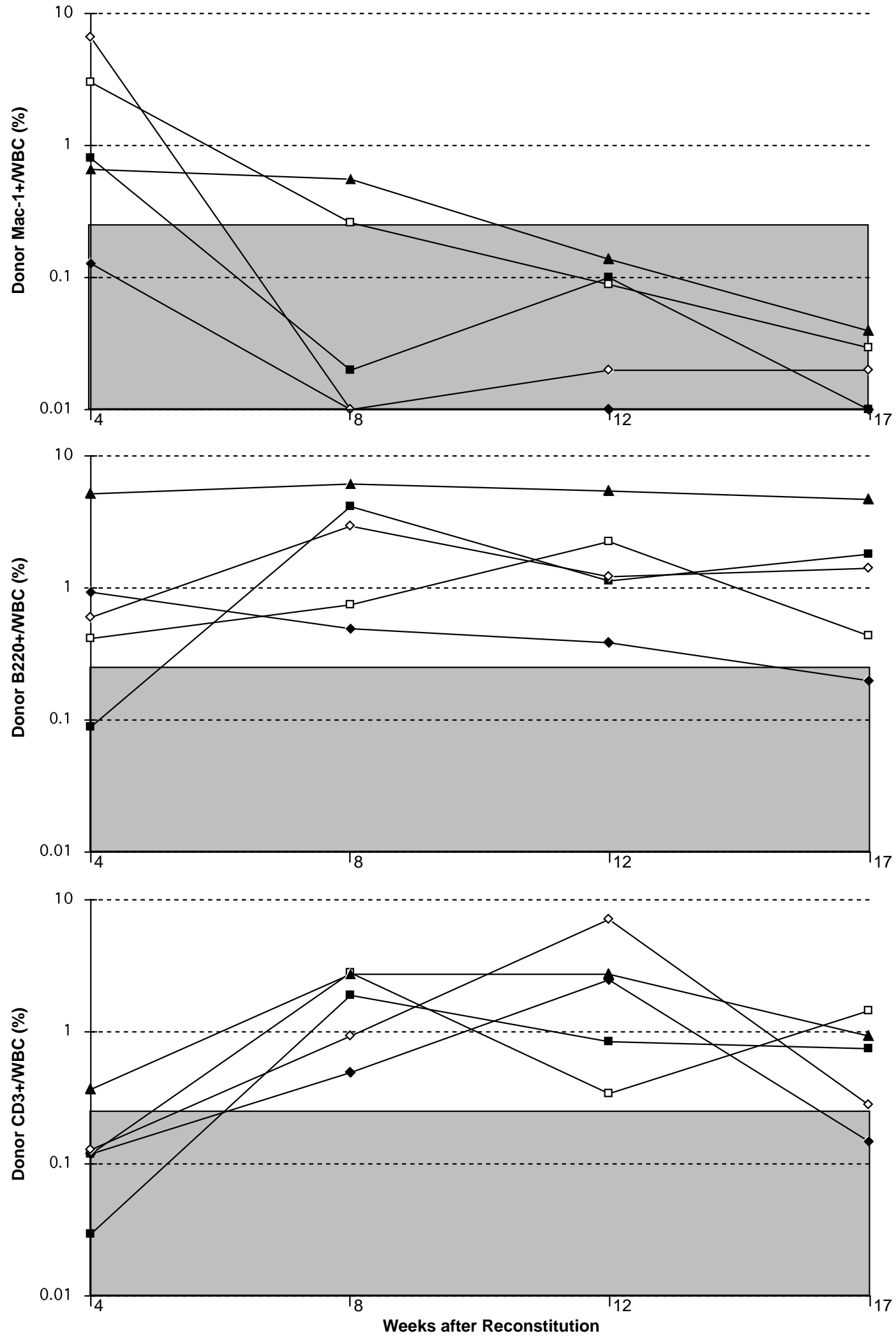

mice competitively reconstituted with $75 \mathrm{Mac}-1^{\mathrm{lo}} \mathrm{CD} 4^{-}$cells. Four of five mice were TMR and one was donor reconstituted only by $\mathrm{B}$ and $\mathrm{T}$ cells. Relative to $\mathrm{Mac}-1^{10} \mathrm{CD} 4^{-}$cells from normal bone marrow, a higher dose of cells from reconstituted mice was required to observe progenitor activity in the competitive reconstitution assay. Nonetheless, Mac- $1^{\mathrm{lo}} \mathrm{CD} 4^{-}$cells from both sources exhibit mainly transient multipotent and oligopotent progenitor activity. 
Fig. 3. Lethally irradiated mice were reconstituted by 60 Thy $-1^{\text {lo }}$ Sca- ${ }^{\text {hi }}$ Lin $^{-}$ Mac- $1^{-} \mathrm{CD} 4^{-}$c-kit ${ }^{+}$cells. 4 weeks later Thy- $1^{\text {lo Sca- }}$ 1 hi Mac- $1^{\text {lo }} \mathrm{CD} 4^{\text {lo }}$ (Mac$1^{\text {lo }} \mathrm{CD} 4^{\mathrm{lo}}$ ) cells were purified by FACS from the bone marrow of these primary recipients and transferred to lethally irradiated secondary recipients. Five secondary recipients received 50 donor-type Mac- $1^{\mathrm{lo}} \mathrm{CD} 4^{\text {lo }}$ cells plus 200,000 recipient-type whole bone marrow cells for radioprotection. Each line represents an individual mouse, and the shaded area represents the range of background signals observed in negative control mice. Three secondary recipients were transiently multilineage reconstituted by donortype cells (closed square, open diamond, filled diamond), one mouse was reconstituted only by donor-type B cells (closed triangles) and one mouse was unreconstituted by donor-type cells (open squares).
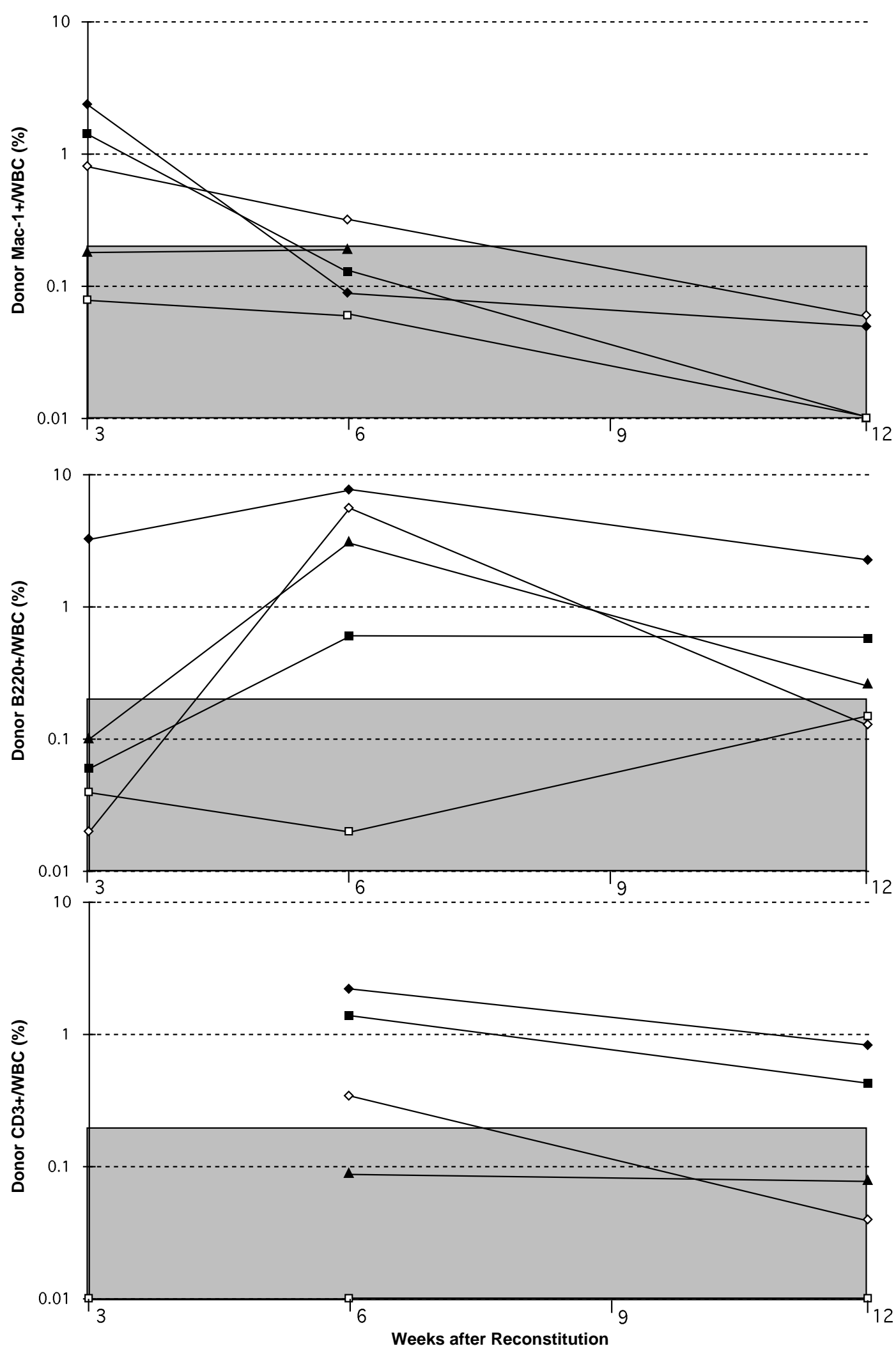

In reconstituted mice, the $\mathrm{Mac}-1^{\mathrm{lo}} \mathrm{CD} 4^{\text {lo }}$ population only exhibited progenitor activity when purified from the bone marrow of mice within 4 weeks of reconstitution. 4 weeks after reconstitution by $\mathrm{Mac}-1^{-} \mathrm{CD} 4^{-} \mathrm{c}-\mathrm{kit}^{+}$cells, bone marrow was harvested from primary recipients and $\mathrm{Mac}-1^{\mathrm{lo}} \mathrm{CD} 4^{\mathrm{lo}}$ cells were purified. 50 of these cells were injected into each of ten 
Table 1. Functional activities of Thy-1 ${ }^{\text {lo }} \mathrm{Sca}^{+} \mathbf{1}^{+} \mathrm{Lin}^{-/ \mathrm{lo}} \mathrm{c}-\mathrm{kit}^{+}$subpopulations purified from normal mice, and mice

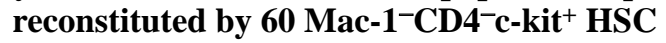

\begin{tabular}{|c|c|c|c|c|c|c|}
\hline & \multicolumn{3}{|c|}{ HSC reconstituted donors } & \multicolumn{3}{|c|}{ Normal donors } \\
\hline & $\mathrm{Mac}^{-}{ }^{-} \mathrm{CD} 4^{-} \mathrm{c}-\mathrm{kit}^{+}$ & $\mathrm{Mac}-1^{\mathrm{lo}} \mathrm{CD} 4^{-}$ & Mac- $1^{\text {lo }} \mathrm{CD} 4^{\text {lo }}$ & Mac-1-CD4 ${ }^{-} \mathrm{c}-\mathrm{kit}^{+}$ & $\mathrm{Mac}-1^{\mathrm{lo}} \mathrm{CD} 4^{-}$ & Mac- $1^{\mathrm{lo}} \mathrm{CD} 4^{\mathrm{lo}}$ \\
\hline Day 12 CFU-S (1/freq) & 15 & $12 \pm 1$ & No activity & $61 \pm 29$ & $14 \pm 4$ & $18 \pm 8$ \\
\hline Clonogenic on stroma $(\%)$ & $31 \pm 14$ & $44 \pm 20$ & 0 & $49 \pm 10$ & $55 \pm 9$ & $40 \pm 5$ \\
\hline Clonogenic in culture (\%) & $67 \pm 10$ & $53 \pm 4$ & 0 & $83 \pm 1$ & 62 & $26 \pm 5$ \\
\hline
\end{tabular}

The percentage of cells clonogenic on stroma was determined by sorting single cells into individual AC-6 stromal cell cultures and then counting the

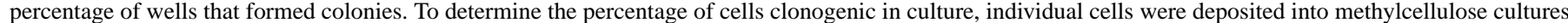
supplemented by IL-3, IL-6 and SIF, cytokines that maximize colony formation by multipotent progenitors. Mac- ${ }^{\text {lo }} \mathrm{CD} 4^{\mathrm{lo}}$ cells from HSC reconstituted donors were obtained from mice that had been reconstituted for 10-15 weeks. Some of the data from normal donors have been published elsewhere and are presented here for comparison purposes only (Morrison and Weissman, 1994; Morrison et al., 1996b). Statistics are presented as means \pm s.d.

secondary recipients, competitively reconstituting four with donor-type cells. Fig. 3 shows five of ten secondary recipients, including the four that became reconstituted by donor-type cells (3 TMR and 1 oligopotent reconstitution). By comparison, 19 of 21 mice injected with $15 \mathrm{Mac}-1^{\mathrm{lo}} \mathrm{CD} 4{ }^{\mathrm{lo}}$ cells purified from normal mice were competitively reconstituted by donor cells (difference significant at $P<0.001$ ). When Mac- $1^{\mathrm{lo}} \mathrm{CD} 4^{\mathrm{lo}}$ cells were purified 8-15 weeks after reconstitution, 50-100 cells did not transfer detectable progenitor activity to any of 25 secondary recipients. Although higher cell doses were required to exhibit progenitor activity, the $\mathrm{Mac}-1^{\mathrm{lo}} \mathrm{CD} 4{ }^{\text {lo }}$ population purified from reconstituted donors within a month of reconstitution exhibited similar types of progenitor activity as the same population from normal bone marrow.

The inefficient engraftment of multipotent progenitor populations from reconstituted mice might be due to either a reduced ability to home to and engraft bone marrow or the presence of a majority of non-progenitor cells within each population. In order to distinguish between these possibilities, we tested the activities of these cells in functional assays that are independent of bone marrow homing properties. The results are summarized in Table 1 . We assayed the day 12 colony forming unit-spleen (CFU-S) activity of all three populations purified from primary recipients $10-15$ weeks after reconstitution. Day 12 CFU-S activity is associated with multipotent progenitors (for example, Spangrude et al., 1988; Morrison and Weissman, 1994). The CFU-S activities of the Mac- $1^{-} \mathrm{CD} 4^{-} \mathrm{c}-$ $\mathrm{kit}^{+}$and $\mathrm{Mac}-1^{\mathrm{lo}} \mathrm{CD} 4^{-}$populations from reconstituted mice were equal to or greater than those from normal mice (Table 1). This is inconsistent with the multipotent progenitor populations from reconstituted mice containing a majority of nonprogenitor cells or progenitors more differentiated than multipotent progenitors.

The ability of single cells to form colonies on AC-6 stroma was also tested. The colonies formed by these populations contained hundreds of thousands of cells and persisted for more than 6 weeks. Progenitors forming such colonies have recently been shown to be equivalent to LTC-IC (MullerSieburg and Riblet, 1996). $31 \%$ of Mac- $1^{-} \mathrm{CD}^{-}{ }^{-} \mathrm{c}-\mathrm{kit}^{+}$cells and $44 \%$ of $\mathrm{Mac}^{1{ }^{\mathrm{lo}} \mathrm{CD} 4^{-}}$cells from reconstituted mice formed such colonies on AC-6 stroma (Table 1). Around 50\% of cells from either population purified from normal marrow formed indistinguishable colonies (Morrison et al., 1996b). The frequency of $\mathrm{Mac}-1^{-} \mathrm{CD} 4^{-} \mathrm{c}-\mathrm{kit}^{+}$cells from reconstituted mice that formed colonies on AC- 6 was modestly but significantly $(P<0.05)$ reduced relative to those from normal bone marrow. Even if this modest reduction resulted entirely from contamination due to non-progenitor cells, it could not account for the observed 8 -fold reduction in engraftment in vivo. The frequency of colony formation by $\mathrm{Mac}-1^{\mathrm{lo}} \mathrm{CD} 4^{-}$ cells did not significantly differ between normal and reconstituted donors.

We tested the ability of these populations to form colonies in methylcellulose supplemented with IL-3, IL-6 and Steel factor $(\mathrm{SIF})$ - cytokines that optimize colony formation by multipotent progenitors (Heimfeld et al., 1991; Tsuji et al., 1992; Morrison et al., 1996b). $67 \%$ of Mac- $1^{-} \mathrm{CD}^{-}{ }^{-} \mathrm{c}-\mathrm{kit}^{+}$cells and $53 \%$ of Mac- $1{ }^{\mathrm{lo}} \mathrm{CD} 4{ }^{-}$cells from reconstituted mice formed colonies in methylcellulose (Table 1). 83 or $62 \%$ of the same populations from normal marrow formed similar colonies under the same conditions. The rate of colony formation from progenitor populations isolated from reconstituted mice was somewhat reduced relative to the same cells from normal marrow, but the differences were not statistically significant. Multipotent progenitors from reconstituted mice might not be able to respond as efficiently as normal bone marrow multipotent progenitors to in vitro clonogenic assays; however, the data are also consistent with the $\mathrm{Mac}-1^{-} \mathrm{CD} 4^{-} \mathrm{c}-\mathrm{kit}^{+}$and Mac$1^{\text {lo }} \mathrm{CD}^{-}$populations from reconstituted mice containing a small but increased proportion of non-progenitor cells. The presence of non-clonogenic cells in the populations from reconstituted mice could contribute to their reduced engraftment efficiency. Based on the in vitro assays, the non-clonogenic Mac- $1^{-} \mathrm{CD} 4^{-} \mathrm{c}-\mathrm{kit}^{+}$cells from reconstituted mice appear to represent less than a third of the population, but the engraftment rate of these cells in irradiated recipients was more than 8 -fold reduced relative to normal bone marrow $\mathrm{Mac}-1^{-} \mathrm{CD} 4^{-} \mathrm{c}-$ $\mathrm{kit}^{+}$cells. The data suggest that the reduced reconstituting efficiency of multipotent progenitors from reconstituted mice is due mainly to a reduced ability of bonafide progenitors to home to and engraft in the bone marrow of recipient mice. Proof of this interpretation depends on the development of an in vivo homing assay for HSC that can be performed using relatively few cells.

The Mac- $1^{\text {lo }} \mathrm{CD} 4^{\text {lo }}$ population, purified from mice that had been reconstituted for 10-15 weeks, had no CFU-S activity or progenitor activity in culture. This is consistent with its lack of progenitor activity in vivo when purified from the bone marrow of mice that have been reconstituted for more than 4 weeks. Mac- $1^{\text {lo }} \mathrm{CD} 4{ }^{\text {lo }}$ progenitors also disappeared during normal aging in old mice (Morrison et al., 1996b). We did not test the CFU-S activity or the progenitor activity in culture of Mac$1^{\text {lo }} \mathrm{CD} 4^{\text {lo }}$ cells from the marrow of primary recipients within 4 weeks of reconstitution. 
Table 2. The presence of multipotent progenitor populations in the bone marrow of mice reconstituted by

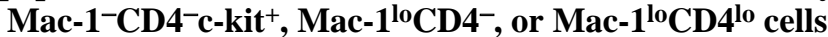
from normal marrow

\begin{tabular}{|c|c|c|c|}
\hline \multirow{2}{*}{$\begin{array}{l}\text { Primary recipients } \\
\text { reconstituted by }\end{array}$} & \multirow{2}{*}{$\begin{array}{l}\text { Time after } \\
\text { reconstitution }\end{array}$} & \multicolumn{2}{|c|}{$\begin{array}{l}\text { Donor-derived progenitors } \\
\text { in primary recipients }\end{array}$} \\
\hline & & Mac-1-CD4- c-kit ${ }^{+}$ & Mac- $1^{\text {lo }} \mathrm{CD} 4^{-}$ \\
\hline \multirow[t]{2}{*}{ Mac-1-CD4- c-kit ${ }^{+}$} & 3-6 weeks & $6 / 9$ & $4 / 9$ \\
\hline & $>6$ weeks & $15 / 16$ & $13 / 14$ \\
\hline \multirow[t]{2}{*}{ Mac- $1^{\text {lo }} \mathrm{CD}^{-}$} & 3-6 weeks & $1 / 9$ & $1 / 9$ \\
\hline & $>6$ weeks & $0 / 1$ & $0 / 1$ \\
\hline \multirow[t]{2}{*}{$\mathrm{Mac}-1^{\mathrm{lo}} \mathrm{CD} 4^{\mathrm{lo}}$} & 3-6 weeks & $0 / 6$ & $0 / 6$ \\
\hline & $>6$ weeks & $1 / 4$ & $1 / 4$ \\
\hline
\end{tabular}

In each case, the number of primary recipients positive for each progenitor population is shown as a proportion of recipients examined. Primary recipients are organized according to the progenitor population that they were reconstituted by. In each case, primary recipients were reconstituted by 60 cells of the given population and their bone marrow was harvested 3 weeks to 8 months later, to be assayed by FACS for the presence of each multipotent progenitor population. The data were compared by pairwise Z-tests to determine if differences were statistically significant. Within or beyond 6 weeks after reconstitution, mice reconstituted by $\mathrm{Mac}-1^{-} \mathrm{CD} 4^{-} \mathrm{c}-\mathrm{kit}^{+}$cells were significantly more likely $(P<0.05$ and $P<0.01$ respectively) than mice reconstituted by either of the other progenitor populations to have detectable donor-derived Mac- $1^{-} \mathrm{CD} 4^{-} \mathrm{c}-\mathrm{kit}^{+}$or Mac- $1^{\mathrm{lo}} \mathrm{CD} 4^{-}$cells. Mice reconstituted by $\mathrm{Mac}-1^{\mathrm{lo}} \mathrm{CD} 4^{-}$cells or Mac- $1^{\mathrm{lo}} \mathrm{CD} 4^{\text {lo }}$ cells did not differ in the frequency of recipients that contained donor progenitor populations.

\section{Multipotent progenitor populations form a lineage}

Having demonstrated that the multipotent progenitor populations from normal bone marrow also exist in reconstituted mice, we studied whether these populations form a lineage. As described above, we found functional Mac- $1^{-} \mathrm{CD} 4^{-} \mathrm{c}-\mathrm{kit}^{+}$, Mac- $1^{\mathrm{lo}} \mathrm{CD} 4^{-}$and $\mathrm{Mac}-1^{\mathrm{lo}} \mathrm{CD} 4{ }^{\text {lo }}$ progenitors in mice reconstituted by 60 Mac- $1^{-} \mathrm{CD}^{-}{ }^{-} \mathrm{c}-\mathrm{kit}^{+}$cells. This demonstrates that the Mac- $1^{-} \mathrm{CD}^{-}{ }^{-} \mathrm{c}-\mathrm{kit}^{+}$population has considerable self-renewal potential as well as the ability to give rise to cells of both other populations. If these populations form a lineage as hypothesized, then mice reconstituted by Mac- $1^{\text {lo }} \mathrm{CD} 4^{-}$cells should contain donor-type Mac- $1^{\mathrm{lo}} \mathrm{CD} 4{ }^{\mathrm{lo}}$ cells and possibly Mac$1^{\mathrm{lo}} \mathrm{CD} 4^{-}$cells but not Mac- $1^{-} \mathrm{CD} 4^{-} \mathrm{c}-\mathrm{kit}^{+}$cells. Similarly, mice reconstituted by Mac- $1^{\text {lo }} \mathrm{CD} 4{ }^{\text {lo }}$ cells should not contain donortype $\mathrm{Mac}-1^{-} \mathrm{CD} 4^{-} \mathrm{c}-\mathrm{kit}{ }^{+}$or $\mathrm{Mac}-1^{\mathrm{lo}} \mathrm{CD} 4^{-}$cells. We systematically examined mice reconstituted by each population to test this hypothesis. Unfortunately, as demonstrated above, cells with the fluorescence profiles of Mac- $1^{\text {lo }} \mathrm{CD} 4{ }^{\text {lo }}$ cells could sometimes be isolated from reconstituted mice, even when there was no progenitor activity in that population. It appears that, in reconstituted mice, certain non-progenitor populations can sometimes be indistinguishable from Mac- $1^{10} \mathrm{CD} 4^{\mathrm{lo}}$ progenitors; therefore, a simple phenotypic analysis was insufficient for detecting $\mathrm{Mac}-1^{\mathrm{lo}} \mathrm{CD} 4^{\mathrm{lo}}$ progenitors and functional assays were required.

We phenotypically analyzed primary recipients reconstituted by each multipotent progenitor population from normal marrow for the presence of donor-derived Mac- $1^{-} \mathrm{CD}^{-} \mathrm{c}-\mathrm{kit}^{+}$ or Mac- $1^{\text {lo }} \mathrm{CD}^{-}$cells. The results are presented in Table 2. Mice reconstituted by $\mathrm{Mac}-1^{-} \mathrm{CD} 4^{-} \mathrm{c}-\mathrm{kit}^{+}$cells almost always contained populations of donor-derived Mac- $1^{-} \mathrm{CD} 4^{-} \mathrm{c}-\mathrm{kit}^{+}$and Mac- $1^{\text {lo }} \mathrm{CD} 4^{-}$cells no matter when the primary recipients were analyzed, from 6 weeks to 8 months after reconstitution.
Between 3 and 6 weeks after reconstitution by $\mathrm{Mac}-1^{-} \mathrm{CD} 4^{-} \mathrm{c}-$ $\mathrm{kit}^{+}$cells, four of nine mice had donor-derived Mac- ${ }^{-} \mathrm{CD} 4^{-} \mathrm{c}-$ $\mathrm{kit}^{+}$and Mac- $1^{\mathrm{lo}} \mathrm{CD} 4^{-}$cells and two mice had donor Mac-1 ${ }^{-}$ $\mathrm{CD}^{-}{ }^{-} \mathrm{c}-\mathrm{kit}^{+}$cells but not Mac- ${ }^{\mathrm{lo}} \mathrm{CD} 4^{-}$cells. Since mice were reconstituted by only $60 \mathrm{Mac}-1^{-} \mathrm{CD} 4^{-} \mathrm{c}-\mathrm{kit}^{+}$cells, Poisson statistics would predict that only two thirds of mice would have their long-bones reconstituted at early time points. The third of Mac- $1^{-} \mathrm{CD} 4^{-} \mathrm{c}-\mathrm{kit}^{+}$reconstituted mice that did not contain detectable donor-type progenitors before 6 weeks after reconstitution may not have had their long bones seeded by donor progenitors. The higher frequency of $\mathrm{Mac}-1^{-} \mathrm{CD} 4^{-} \mathrm{c}-\mathrm{kit}^{+}$ reconstituted mice containing donor-derived progenitors at later time points may reflect seeding of the long bones by donor progenitors derived from other bones that were initially reconstituted. The frequencies of the donor-derived progenitor populations were equal to or lower than the same populations in age-matched normal bone marrow controls. The phenotypic analyses are consistent with the functional analyses described earlier in demonstrating that $\mathrm{Mac}-1^{-} \mathrm{CD} 4^{-} \mathrm{c}-\mathrm{kit}^{+}$cells are capable of long-term self-renewal as well as giving rise to Mac$1^{\text {lo }} \mathrm{CD}^{-}{ }^{-}$cells over the short-term and long-term.

Mac- $1^{\text {lo }} \mathrm{CD}^{-}{ }^{-}$and $\mathrm{Mac}-1^{\mathrm{lo}} \mathrm{CD} 4{ }^{\text {lo }}$ cells usually only give rise to transient reconstitution. In around $90 \%$ of cases, donor-type myeloid cells in mice reconstituted by limit-dilution doses of these populations become undetectable between 6 and 8 weeks after reconstitution (Morrison and Weissman, 1994). After reconstituted mice lost myeloid lineage chimerism, it was never possible to transfer donor-type multipotent progenitor activity to secondary recipients (data not shown). This demonstrates that the vast majority of Mac- ${ }^{\text {lo }}$ progenitors self-renew for less than 6 weeks; therefore, donor-derived multipotent progenitors should mainly be found in primary recipients within 6 weeks of reconstitution by limiting doses of transient progenitors, if at all. In consideration of this, we split our analyses of primary recipients into those conducted within 6 weeks of reconstitution and those conducted after 6 weeks of reconstitution. Beyond 6 weeks after reconstitution by Mac$1^{\mathrm{lo}} \mathrm{CD}^{-}$cells, donor-derived $\mathrm{Mac}-1^{-} \mathrm{CD} 4^{-} \mathrm{c}-\mathrm{kit}^{+}$or $\mathrm{Mac}-$ $1^{\text {lo }} \mathrm{CD} 4^{-}$populations were undetectable in the only primary recipient available to be analyzed. Within 6 weeks after Mac$1^{\mathrm{lo}} \mathrm{CD} 4^{-}$reconstitution, donor-derived Mac- $1^{-} \mathrm{CD} 4^{-} \mathrm{c}-\mathrm{kit}^{+}$and Mac- $1^{\text {lo }} \mathrm{CD}^{-}{ }^{-}$cells were only detected in 1 of 9 mice. Thus Mac- $1^{\text {lo } C D} 4^{-}$cells were unable to consistently give rise to Mac- $1^{-} \mathrm{CD} 4^{-} \mathrm{c}-\mathrm{kit}^{+}$cells. The observation of one recipient with Mac- $1^{-} \mathrm{CD} 4^{-} \mathrm{c}-\mathrm{kit}^{+}$cells was consistent with the observation that $15 \%$ of primary recipients reconstituted by Mac- $1^{\text {lo }} \mathrm{CD} 4-$ cells become long-term multilineage reconstituted (Morrison and Weissman, 1994), perhaps due to contamination by Mac$1^{-} \mathrm{CD} 4^{-} \mathrm{c}-\mathrm{kit}^{+}$progenitors. We were unable to observe convincing evidence of $\mathrm{Mac}-1^{\mathrm{lo}} \mathrm{CD}^{-}{ }^{-}$self-renewal in the bone marrow.

The Mac- $1^{\text {lo }} \mathrm{CD} 4^{\text {lo }}$ population gave rise to detectable Mac$1^{-} \mathrm{CD} 4^{-} \mathrm{c}-\mathrm{kit}^{+}$or $\mathrm{Mac}-1^{\mathrm{lo}} \mathrm{CD} 4^{-}$cells in only one of ten recipients. The one recipient that contained both donor Mac- $1^{-} \mathrm{CD} 4^{-}$ c-kit ${ }^{+}$and Mac- $1^{\text {lo }} \mathrm{CD}^{-}$cells was LTMR by donor-type cells. It has previously been shown that $7 \%$ of $\mathrm{Mac}-1^{\mathrm{lo}} \mathrm{CD} 4^{\text {lo }}$ cells yield LTMR (Morrison and Weissman, 1994).

In an effort to determine whether Mac- $1^{\mathrm{lo}} \mathrm{CD} 4^{-}$cells give rise to Mac- $1^{\text {lo }} \mathrm{CD} 4{ }^{\text {lo }}$ cells, Mac- $1^{\mathrm{lo}} \mathrm{CD} 4^{\text {lo }}$ cells were purified by two consecutive sorts from the bone marrow of three mice, processed independently, that had been reconstituted by Mac- 
$1^{\text {lo }} \mathrm{CD} 4^{-}$cells $2-4$ weeks previously. 50 of these Mac- $1^{\text {lo }} \mathrm{CD} 4^{\text {lo }}$ cells were transferred to each of nine secondary recipients in a competitive reconstitution assay. One recipient died and one recipient was unreconstituted by donor-type cells. Four secondary recipients were TMR and three were reconstituted only by donor B cells. Roughly equal proportions of transient multipotent progenitor activity and B lineage progenitor activity are also observed from Mac- $1^{10} \mathrm{CD} 4^{\text {lo }}$ cells purified from normal bone marrow. These data demonstrate that Mac$1^{\text {lo }} \mathrm{CD} 4^{-}$cells give rise to functional Mac- $1^{10} \mathrm{CD} 4^{10}$ cells within 4 weeks of reconstitution.

Do Mac- $1^{\text {lo }} \mathrm{CD} 4^{\text {lo }}$ cells self-renew in the bone marrow? 2-4 weeks after reconstitution, Mac- $1^{\mathrm{lo}} \mathrm{CD} 4^{\mathrm{lo}}$ cells were purified by two consecutive sorts from the bone marrow of two primary recipients of Mac- $1^{\text {lo }} \mathrm{CD} 4^{\text {lo }}$ cells. 50 Mac- $1^{\text {lo }} \mathrm{CD} 4^{\text {lo }}$ cells were transferred to each of five secondary recipients in competitive reconstitution assays. None of these recipients became reconstituted by donor-type cells. The data suggest that most Mac$1^{\text {lo }} \mathrm{CD} 4^{\text {lo }}$ cells are not capable of sufficient self-renewal to be detected in the bone marrow 2-4 weeks after reconstitution.

\section{Mac- $1^{\text {lo }} \mathrm{CD} 4$ - cells but not Mac- $1^{\text {lo }} \mathrm{CD} 4^{\text {lo }}$ cells self- renew in the spleen}

The Mac- $1^{\mathrm{lo}} \mathrm{CD} 4^{-}$and Mac- $1^{1 \mathrm{lo}} \mathrm{CD} 4^{1 \mathrm{lo}}$ populations did not exhibit detectable self-renewal in the bone marrow, but it has been observed that the spleen is the primary site of stem cell proliferation at early times after reconstitution (Osawa et al., 1996). We examined the ability of the Mac- $-1^{\mathrm{lo}} \mathrm{CD} 4^{-}$and $\mathrm{Mac}-1^{\mathrm{lo}} \mathrm{CD} 4^{1 \mathrm{lo}}$ populations to self-renew or give rise to other multipotent progenitor populations in the spleen at very early times after reconstitution. Lethally irradiated recipient-type mice were injected with 35 cells of either donor-type progenitor population. 7 or 21 days after reconstitution, the spleens were examined by FACS for the presence of multipotent progenitor populations (Table 3). At 7 days after reconstitution, mice reconstituted by Mac$1^{\mathrm{lo}} \mathrm{CD} 4^{-}$cells always had greatly expanded numbers $(0.01$ $0.03 \%$ ) of donor Mac- $1^{10} \mathrm{CD}^{-}$cells in their spleens, but did not have Mac- $1^{-} \mathrm{CD} 4{ }^{-} \mathrm{c}-\mathrm{kit}^{+}$cells detectable above background $(<0.002 \%)$. To confirm that this represented self-renewal of

Table 3. The presence of multipotent progenitor populations in the spleens of mice reconstituted by Mac$1^{10} \mathrm{CD4}^{-}$, or $\mathrm{Mac}_{-1}{ }^{10} \mathrm{CD}^{10}$ cells from normal marrow

\begin{tabular}{lccc}
\hline Primary recipients & $\begin{array}{c}\text { Time after } \\
\text { reconstituted by }\end{array}$ & \multicolumn{2}{c}{$\begin{array}{c}\text { Donor-derived progenitors } \\
\text { in primary recipients }\end{array}$} \\
\cline { 3 - 4 } Mac- $1{ }^{\text {lo }} \mathrm{CD} 4^{-}$ & 7 days & $0 / 4$ & $4 / 4$ \\
& 21 days & $0 / 5$ & $0 / 5$ \\
Mac- $1{ }^{\text {lo }} \mathrm{CD} 4{ }^{\text {lo }}$ & 7 days & $1 / 11$ & $2 / 20$ \\
& 21 days & $0 / 4$ & $0 / 4$
\end{tabular}

In each case, the number of primary recipients positive for each progenitor population is shown as a proportion of recipients examined. Primary recipients are organized according to the progenitor population that they were reconstituted by. In each case, primary recipients were reconstituted by 35 donor-type cells of the given population and their spleens were harvested 7 or 21 days later to be assayed by FACS for the presence of each multipotent progenitor population. The only significant difference between comparable statistics was that Mac- $1^{\mathrm{lo}} \mathrm{CD} 4^{-}$progenitors were significantly more likely to give rise to Mac- $1^{\mathrm{lo}} \mathrm{CD} 4^{-}$cells 7 days after reconstitution than Mac- $1^{\mathrm{lo}} \mathrm{CD} 4^{\mathrm{lo}}$ progenitors $(P<0.05)$.
Mac- $1^{\text {lo }} \mathrm{CD}^{-}$progenitors, these cells were isolated from the spleens of reconstituted mice and were found to have day 12 CFU-S activity indistinguishable from the same population isolated from normal bone marrow (1 colony for every 15 cells injected). By 21 days after reconstitution, it was no longer possible to detect the donor progenitor populations in the spleen. Of mice reconstituted by Mac- $1^{10} \mathrm{CD} 4^{\text {lo }}$ cells after 7 days, one of eleven mice contained both Mac- $1^{\mathrm{lo}} \mathrm{CD} 4^{-}$and $\mathrm{Mac}-1^{-} \mathrm{CD} 4^{-}$ c-kit ${ }^{+}$cells and another mouse contained Mac- $1^{\text {lo }} \mathrm{CD}^{-}{ }^{-}$cells. By 21 days after reconstitution, donor progenitors were again no longer detectable. At the dose of donor cells used, each spleen should have been reconstituted by an average of two progenitor cells based on CFU-S frequencies. Thus the occurrence of progenitor populations in the spleens of mice reconstituted by Mac$1^{\mathrm{lo}} \mathrm{CD} 4{ }^{1 \mathrm{lo}}$ cells could be explained by low levels of contamination from each of the Mac- $1^{-} \mathrm{CD} 4^{-} \mathrm{c}-\mathrm{kit}^{+}$and $\mathrm{Mac}-1^{\mathrm{lo}} \mathrm{CD} 4^{-}$ populations. Alternately, it remains possible that Mac- $1^{\mathrm{lo}} \mathrm{CD} 4^{\mathrm{lo}}$ cells can give rise to the other populations under rare circumstances. Overall, the spleen reconstitution data demonstrate that at least half of Mac- $1^{10} \mathrm{CD} 4-$ cells have self-renewal potential that can be observed in the spleen a week after reconstitution. Self-renewal by Mac- $1^{10} \mathrm{CD}^{-}$cells at later times in the bone marrow and/or spleen could occur but only at much lower levels than we were unable to detect.

Most Mac- $1^{\text {lo }} \mathrm{CD} 4^{\text {lo }}$ cells do not exhibit detectable selfrenewal in the spleen. Two mice reconstituted by 35 Mac$1^{10} \mathrm{CD} 4{ }^{10}$ cells 7 days earlier were examined by FACS for the presence of Mac- $1^{10} \mathrm{CD} 4{ }^{10}$ cells in their spleens. It was not possible to isolate significant numbers $(<0.002 \%)$ of Mac$1^{\mathrm{lo}} \mathrm{CD} 4^{\mathrm{lo}}$ cells from the spleens of either of these mice. An additional five mice reconstituted by $35 \mathrm{Mac}-1^{\mathrm{lo}} \mathrm{CD} 4^{\text {lo }}$ cells did contain isolatable Mac- $1^{10} \mathrm{CD} 4^{\text {lo }}$ cells 7 days after reconstitution, but these cells had no detectable day 12 CFU-S activity. The lack of CFU-S activity in these cells is inconsistent with them being transiently reconstituting multipotent progenitors that arose by self-renewal of Mac- $1^{\mathrm{lo}} \mathrm{CD} 44^{\text {lo }}$ cells transplanted from normal marrow. As described above (Table 1), we were often able to isolate cells from reconstituted mice with fluorescence profiles consistent with Mac- $1^{10} \mathrm{CD} 4{ }^{10}$ progenitors, but that had no detectable progenitor activity. We presume these cells derive from some non-progenitor population that coincidentally can appear similar to Mac- $1^{10} \mathrm{CD} 4{ }^{\text {lo }}$ progenitors in reconstituted mice.

\section{A quantitative estimate of self-renewal potential}

Primary recipients in our experiments were reconstituted by 60 cells, such that the long bones were reconstituted by an average of a single progenitor. The number of Mac- $1^{-} \mathrm{CD}^{-} \mathrm{c}-\mathrm{kit}^{+}$cells found at later times in the long bones of these reconstituted mice provides a quantitative measure of self-renewal potential. 4 weeks after reconstitution by $\mathrm{Mac}-1^{-} \mathrm{CD} 4^{-} \mathrm{c}-\mathrm{kit}^{+}$cells, the long bones of recipients contained $0.0046 \pm 0.0005 \%$ Mac- $1^{-}$ $\mathrm{CD}^{-}{ }^{-} \mathrm{c}-\mathrm{kit}^{+}$cells. This corresponds to an average of $1400 \mathrm{Mac}-$ $1^{-} \mathrm{CD} 4{ }^{-} \mathrm{c}-\mathrm{kit}^{+}$cells per recipient's long bones. 8 months after reconstitution, recipients averaged $0.03 \% \mathrm{Mac}-1^{-} \mathrm{CD} 4{ }^{-} \mathrm{c}-\mathrm{kit}^{+}$ cells in the long bones. This corresponded to an average total

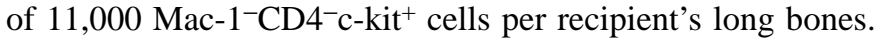
This 11,000 -fold expansion of a single Mac- $1^{-} \mathrm{CD} 4{ }^{-} \mathrm{c}-\mathrm{kit}^{+}$cell is likely to be an underestimate because some Mac- $1^{-} \mathrm{CD} 4^{-} \mathrm{c}-$ $\mathrm{kit}^{+}$cells were likely to have differentiated during 8 months of hematopoiesis. 
Poisson statistics predict that $63 \%$ of mice should have had their long bones seeded by donor-type progenitor cells in mice injected with 60 cells (Henry et al., 1980). We transferred whole bone marrow from the four long bones of mice injected with $60 \mathrm{Mac}^{-} 1^{-} \mathrm{CD} 4^{-} \mathrm{c}-\mathrm{kit}^{+}$cells to secondary recipients. All of the bone marrow recovered from the femurs and tibias of each primary recipient was divided into aliquots and transferred along with $2 \times 10^{5}$ recipient-type whole bone marrow cells into each of 3-5 secondary recipients. Table 4 shows the results. 2 weeks after reconstitution, only $50 \%$ of secondary recipients were reconstituted by donor-type cells, consistent with the prediction that only $63 \%$ of primary recipients should have donor-type progenitors in their long bones. Over time, however, the frequency of secondary recipients reconstituted by donor-type cells increased to over $90 \%$. At 4 weeks after reconstitution, only half of the secondary recipients became LTMR with donor-type cells. By 9 weeks after reconstitution, and continuing for at least 8 months, over $90 \%$ of secondary recipients became LTMR. This further demonstrates the remarkable self-renewal potential of $\mathrm{Mac}-1^{-} \mathrm{CD} 4^{-} \mathrm{c}-\mathrm{kit}^{+}$cells . More importantly, they suggest that bones not initially seeded by injected HSC can become reconstituted later by sufficient donor-type HSC to transfer LTMR to multiple secondary recipients. Perhaps the low-level circulation of HSC in blood (Goodman and Hodgson, 1962) constantly redistributes progenitors throughout all hematopoietic environments. On average, efflux of HSC from the long bones may nearly equal influx. If not, then the calculations above would underestimate the self-renewal of HSC.

\section{DISCUSSION}

We have demonstrated that reconstituted mice contain the same multipotent hematopoietic progenitor populations, with similar properties, as normal bone marrow. Although the progenitor populations purified from reconstituted mice are less efficient at engrafting the bone marrow of recipient mice, they function as well or almost as well as normal bone marrow multipotent progenitors in CFU-S and in vitro assays of multipotent progenitor activity. Mac- $1^{-} \mathrm{CD} 4{ }^{-} \mathrm{c}-\mathrm{kit}^{+}$cells and Mac- $1^{\mathrm{lo}} \mathrm{CD} 4^{-}$cells from cytokine-mobilized mice (Morrison et al., 1997) and from old mice (Morrison et al., 1996b) are also less efficient than normal bone marrow HSC at engrafting the bone marrow of irradiated recipients. In those cases, both populations were as effective as normal bone marrow HSC in forming primitive colonies in methylcellulose, day $12 \mathrm{CFU}-\mathrm{S}$, or long-term cultures on hematopoi- etic stroma. It was proposed that the inefficient bone marrow engraftment of multipotent progenitors from cytokinemobilized and old mice was due to changes in homing receptor function that impaired homing to bone marrow. We hypothesize that multipotent progenitors from reconstituted mice are also less efficient at homing to and engrafting the bone marrow. An alternate possibility is that, in reconstituted mice, most cells with the surface marker phenotypes of multipotent progenitors may have differentiated into progenitors that do not detectably engraft in vivo but which have late CFU-S activity and form primitive colonies in vitro. While this possibility should be acknowledged, no such progenitor population has yet been identified; furthermore, the cytokinemobilized Mac- $1^{-} \mathrm{CD} 4^{-} \mathrm{c}-\mathrm{kit}^{+}$and $\mathrm{Mac}-1^{\mathrm{lo}} \mathrm{CD} 4^{-}$populations did not appear to contain significant numbers of early myeloerythroid committed progenitors because few cells proliferated in response to IL-3 or GM-CSF alone (Morrison et al., 1997). In support of the hypothesis that HSC from old, cytokine-mobilized and reconstituted mice may have different homing properties than normal HSC, we found a change in adhesion molecule expression in all these circumstances, which could at least partially account for reduced bone marrow engraftment (D. E. W., I. L. W., S. J. M., unpublished data). In order to prove that HSC from reconstituted mice are impaired in their bone marrow homing ability, it will be necessary to directly follow the localization of such cells in vivo after i.v. or intra-arterial injection. Such assays are not currently possible with the small numbers of cells that can be obtained from rare populations such as HSC.

Spangrude et al. (1995) found that Thy- ${ }^{10} \mathrm{Sca}-1^{+} \mathrm{Lin}^{-}$ Rho $123^{\text {lo }}$ cells purified from reconstituted mice did not exhibit as much activity in competitive reconstitution assays as the same cells from normal mice. They concluded that there is an expansion of stem cell phenotype but not function in reconstituted mice. We agree that HSC from reconstituted mice do not function as well as normal bone marrow HSC in competitive reconstitution assays; however, our data demonstrate that the majority of multipotent progenitors from reconstituted mice behave much like normal multipotent progenitors in other assays. We conclude that Mac- $1^{-} \mathrm{CD} 4^{-} \mathrm{c}-\mathrm{kit}^{+}$and $\mathrm{Mac}-\mathrm{1}^{\mathrm{lo}} \mathrm{CD} 4{ }^{-}$ cells in reconstituted mice are long-term and transiently selfrenewing HSC, but their ability to engraft mice is reduced, perhaps by changes in homing properties. Changes in homing properties could reduce engraftment by acting at any of a number of levels. For example, such changes may confer the tendency for progenitor cells to home to tissues not permissive for hematopoiesis, or progenitors may be impaired in the ability to adhere to bone marrow endothelium, or to extravasate

Table 4. Transfer of whole bone marrow from primary recipients competitively reconstituted by 60 Thy-1 ${ }^{10} \mathrm{Sca}^{-1} \mathrm{Lin}^{-}$ Mac-1- CD4- $^{-}$-kit ${ }^{+}$cells at various times after reconstitution

\begin{tabular}{|c|c|c|c|c|c|}
\hline \multirow[b]{2}{*}{ Time of transfer } & \multirow[b]{2}{*}{$n$} & \multicolumn{4}{|c|}{ Donor cell reconstitution profiles of secondary recipients (\%) } \\
\hline & & $\begin{array}{l}\text { Long-term } \\
\text { multilineage }\end{array}$ & $\begin{array}{c}\text { Transient } \\
\text { multilineage }\end{array}$ & Oligoclonal & $\begin{array}{l}\text { No donor cell } \\
\text { reconstitution }\end{array}$ \\
\hline 2 weeks & 29 & 3 & 7 & 38 & 52 \\
\hline 4 weeks & 12 & 50 & 42 & 8 & 0 \\
\hline $8-9$ weeks & 16 & 81 & 6 & 13 & 0 \\
\hline 9-10 months & 24 & 92 & 4 & 0 & 4 \\
\hline
\end{tabular}

Whole bone marrow from the four long bones of each primary recipient was used to competitively reconstitute three to five secondary recipients. $n$ refers to the number of secondary recipients reconstituted at each time point. 
into the marrow, or to localize to a permissive microenvironment once inside the marrow.

The multipotent progenitor populations described in this study form a lineage in which Mac- $1^{-} \mathrm{CD} 4^{-} \mathrm{c}-\mathrm{kit}^{+}$cells give rise to Mac- $1^{\text {lo }} \mathrm{CD}^{-}$cells, which in turn give rise to functional Mac- $1^{10} \mathrm{CD} 4{ }^{\text {lo }}$ cells. Most Mac- $1^{-} \mathrm{CD} 4^{-} \mathrm{c}-\mathrm{kit}^{+}$cells had longterm self-renewal potential. At least half of Mac- $1^{10} \mathrm{CD} 4^{-}$cells had detectable, but transient self-renewal potential. Mac$1^{\text {lo }} \mathrm{CD} 4^{\text {lo }}$ cells had no detectable self-renewal potential. These three populations include all multipotent progenitor cells isolatable from bone marrow (Uchida and Weissman, 1992). Therefore, this lineage includes all multipotent progenitors from long-term self-renewing HSC, to the most mature multipotent progenitors prior to, or in the process of, lineage commitment.

HSC are defined by the ability of single cells to self-renew and to give rise to all classes of blood cells (Siminovitch et al., 1963; Morrison et al., 1995). It was previously demonstrated that limit dilution doses of $\mathrm{Mac}-1^{-} \mathrm{CD}^{-}{ }^{-} \mathrm{c}-\mathrm{kit}^{+}$and Mac$1^{\text {lo }} \mathrm{CD}^{-}$cells give rise to monocytes, granulocytes, B cells and $\mathrm{T}$ cells (Morrison and Weissman, 1994). Limit dilution doses of Mac- $1^{\text {lo }} \mathrm{CD} 4^{\text {lo }}$ cells sometimes exhibited multipotent progenitor activity and sometimes only B lineage progenitor activity (as observed in the blood) (Morrison and Weissman, 1994). The reduced colony formation in methylcellulose culture by $\mathrm{Mac}-1^{\mathrm{lo}} \mathrm{CD} 4^{\text {lo }}$ cells from normal bone marrow relative to the other multipotent progenitors from normal bone marrow (Table 1) is consistent with Mac- $1^{\text {lo }} \mathrm{CD} 4^{\text {lo }}$ cells containing lymphoid committed progenitors. At the population level, Thy- $1^{\text {lo }} \mathrm{Sca}-1^{+} \mathrm{Lin}^{-/ / \mathrm{lo}}$ cells also give rise to erythrocytes, platelets (Uchida et al., 1994) and natural killer cells (Aguila, Uchida, Weissman unpublished data). Therefore cells in the Mac- $1^{-} \mathrm{CD} 4^{-} \mathrm{c}-\mathrm{kit}^{+}$and $\mathrm{Mac}-1^{\mathrm{lo}} \mathrm{CD} 4^{-}$populations may be pluripotent. This study is the first in which the self-renewal potentials of each $\mathrm{Thy}-1^{\mathrm{lo}} \mathrm{Sca}-1^{+} \mathrm{Lin}^{-/ l o}$ subpopulation is explicitly examined. Most Mac- $1^{-} \mathrm{CD}^{-}{ }^{-} \mathrm{c}-\mathrm{kit}^{+}$and Mac$1^{\text {lo }} \mathrm{CD}^{-}{ }^{-}$cells had self-renewal potential, while there was no evidence for self-renewal of Mac- $1^{\text {lo }} \mathrm{CD} 4^{\text {lo }}$ cells. Thus both Mac- $1^{-} \mathrm{CD} 4^{-} \mathrm{c}-\mathrm{kit}^{+}$and $\mathrm{Mac}-1^{\mathrm{lo}} \mathrm{CD} 4^{-}$populations fulfill the criteria of HSC (Siminovitch et al., 1963), but Mac- $1^{\text {lo }} \mathrm{CD}^{\mathrm{lo}}$ cells do not. Those who would define HSC as having long-term self-renewal potential might consider only the Mac- $1^{-}{ }^{-} D 4^{-} \mathrm{c}-$ $\mathrm{kit}^{+}$subset as HSC, but this is a semantic issue.

The markers used to identify the progenitor populations described in this study allow the purification of multipotent progenitors and the separation of long-term and transient progenitors. Nonetheless, the Mac- $1^{-} \mathrm{CD} 4^{-} \mathrm{c}-\mathrm{kit}^{+}$, Mac- $1^{\mathrm{lo}} \mathrm{CD} 4{ }^{-}$, and Mac- $1^{\mathrm{lo}} \mathrm{CD} 4{ }^{\mathrm{lo}}$ populations do not perfectly separate longterm and transient progenitors (Morrison and Weissman, 1994). In the same way, the data in Tables 2 and 3 demonstrate that in a low frequency of reconstituted mice, progenitor populations can be detected that would not be predicted by the lineage hypothesis. The frequency of such observations is consistent with the frequency of long-term self-renewing progenitors observed within the transiently reconstituting populations (Morrison and Weissman, 1994). Given the limitations in the ability to completely eliminate long-term progenitors from Mac- $1^{1 \mathrm{o}}$ populations, the data are consistent with the lineage hypothesis. However, it is also possible that, under rare circumstances, a Mac- $1^{\text {lo }}$ progenitor might give rise to a longterm reconstituting $\mathrm{Mac}-1^{-}$progenitor. If this were true, the three populations would still form a lineage as demonstrated, but under rare circumstances the lineage might operate in reverse. The data in this and previous studies rule out the possibility that the three multipotent progenitor populations only arise from additional progenitor population(s).

Lineages of committed hematopoietic progenitors have previously been identified in the B (Hardy et al., 1991) and T (for example Guidos et al., 1990; Shortman, 1992; Kraft et al., 1993; Wu et al., 1996) lineages. The identification of a lineage of multipotent progenitors, in which each intermediate can be independently purified, provides a tool for elucidating the genetic regulation of self-renewal and lineage commitment. Each population in this lineage is similar in phenotype and developmental potential. Yet within the lineage there is a transition from long-term to undetectable self-renewal potential. Similarly, Mac- $1^{-} \mathrm{CD} 4{ }^{-} \mathrm{c}-\mathrm{kit}^{+}$cells are pluripotent, while Mac$1^{\text {lo }} \mathrm{CD} 4^{\mathrm{lo}}$ cells may be in the process of lineage commitment. The genes whose expression regulates self-renewal or the earliest stages of lineage commitment should be differentially expressed by the populations of this lineage. Using single cell analyses of gene expression and enzyme activity, we have identified candidate genes involved in the regulation of self-renewal and lineage commitment. Telomerase (Morrison et al., 1996a) and Ikaros isoforms (C. Klug, S. J. M., I. L. W., unpublished data) are differentially expressed among the multipotent progenitor populations. We expect that further analyses will yield more extensive insight into which genes regulate self-renewal and lineage commitment.

We thank Libuse Jerabek for laboratory management, Tim Knaak and Jack Sun for FACS machine operation, Veronica Braunstein and Andraea Nicolau for antibody preparation, Lucino Hidalgo and Ricardo Salazaar for animal care. Thanks to Koichi Akashi for expert assistance with methylcellulose assays. S. J. M. was a Howard Hughes Medical Institute Predoctoral Fellow. D. E. W. is a Howard Hughes Medical Institute Medical Student Fellow. This work was supported by National Cancer Institute Grant CA42551.

\section{REFERENCES}

Goodman, J. W. and Hodgson, G. S. (1962). Evidence for stem cells in the peripheral blood of mice. Blood 19, 702-714.

Guidos, C. J., Danska, J. S., Fathman, C. G. and Weissman, I. L. (1990). T cell receptor-mediated negative selection of autoreactive $\mathrm{T}$ lymphocyte precursors occurs after commitment to the CD4 or CD8 lineages. J. Exp. Med. 172, 835-846.

Hardy, R. R., Carmack, C. E., Shinton, S. A., Kemp, J. D. and Hayakawa, K. (1991). Resolution and characterization of pro-B and pre-pro-B cell stages in normal mouse bone marrow. J. Exp. Med. 173, 1213-1225.

Heimfeld, S., Hudak, S., Weissman, I. and Rennick, D. (1991). The in vitro response of phenotypically defined mouse stem cells and myeloerythroid progenitors to single or multiple growth factors. Proc. Natl. Acad. Sci., USA 88, 9902-9906.

Hellman, S., Botnick, L. E., Hannon, E. C. and Vigneulle, R. M. (1978). Proliferative capacity of murine hematopoietic stem cells. Proc. Natl. Acad. Sci., USA 75, 490-494.

Henry, C., Marbrook, J., Vann, D. C., Kodlin, D. and Wofsy, C. (1980). Limiting dilution analysis. In Selected Methods in Cellular Immunology' (ed B. B. Mishell and S. M. Shiigi), pp. 138-152. San Francisco, California: W.J. Freeman and Company.

Kay, H. E. M. (1965). How many cell-generations? Lancet 2, 418-419.

Kraft, D. L., Weissman, I. L. and Waller, E. K. (1993). Differentiation of CD3-4-8- human fetal thymocytes in vivo: characterization of a CD3-4+8intermediate. J. Exp. Med. 178, 265-277.

Micklem, H. S. and Ogden, D. A. (1976). Aging of hematopoietic stem cell 
populations in the mouse. In Stem Cells of Renewing Cell Populations (ed. A. B. Cairnie, P. K. Lala, and D. G. Osmond), pp. 331-341. New York: Academic Press.

Morrison, S., Prowse, K. R., Ho, P. and Weissman, I. (1996a). Telomerase activity in hematopoietic cells is associated with self-renewal potential Immunity 5, 207-216.

Morrison, S. J., Uchida, N. and Weissman, I. L. (1995). The biology of hematopoietic stem cells. Annual Reviews in Cell and Developmental Biology 11, 35-71.

Morrison, S. J., Wandycz, A. M., Akashi, K., Globerson, A. and Weissman, I. L. (1996b). The aging of hematopoietic stem cells. Nature Medicine 2, 1011-1016.

Morrison, S. J. and Weissman, I. L. (1994). The long-term repopulating subset of hematopoietic stem cells is deterministic and isolatable by phenotype. Immunity 1, 661-73.

Morrison, S. J., Wright, D. E. and Weissman, I. L. (1997). Cyclophosphamide/G-CSF induces hematopoietic stem cells to proliferate prior to mobilization. Proc. Natl. Acad. Sci., USA 94, 1908-1913.

Muller-Sieburg, C. E. and Riblet, R. (1996). Genetic control of the frequency of hematopoietic stem cells in mice: mapping of a candidate locus to chromosome 1. J. Exp. Med. 183, 1141-1150.

Osawa, M., Nakamura, K., Nishi, N., Takahashi, N., Tokuomoto, Y., Inoue, H. and Nakauchi, H. (1996). In vivo self-renewal of c-kit ${ }^{+}$Sca- $1^{+}$Lin $^{\text {low/- }}$ hemopoietic stem cells. J. Immunol. 156, 3207-3214.

Parks, D. R. and Herzenberg, L. A. (1984). Fluorescence activated cell sorting: theory, experimental optimization, and applications in lymphoid cell biology. Methods in Enzymology 108, 197-241.

Rosendaal, M., Hodgson, G. S. and Bradley, T. R. (1979). Organization of haemopoietic stem cells: the generation age hypothesis. Cell and Tissue Kinetics 12, 17-29.
Shortman, K. (1992). Cellular aspects of early T-cell development. Current Opinion in Immunology 4, 140-146.

Siminovitch, L., McCulloch, E. and Till, J. (1963). The distribution of colony-forming cells among spleen colonies. J. Cell. Comp. Physiol. 62, 327336.

Smith, L. H. and Clayton, M. L. (1970). Distribution of injected 59Fe in mice. Experimental Hematology 20, 82-86.

Spangrude, G. J., Brooks, D. M. and Tumas, D. B. (1995). Long-term repopulation of irradiated mice with limiting numbers of purified hematopoietic stem cells: in vivo expansion of stem cell phenotype but not function. Blood 85, 1006-16.

Spangrude, G. J., Heimfeld, S. and Weissman, I. L. (1988). Purification and characterization of mouse hematopoietic stem cells. Science 241, 58-62.

Tsuji, K., Lyman, S. D., Sudo, T., Clark, S. C. and Ogawa, M. (1992). Enhancement of murine hematopoiesis by synergistic interactions between steel factor (ligand for c-kit), interleukin-11, and other early acting factors in culture. Blood 79, 2855-2860.

Uchida, N., Aguila, H. L., Fleming, W. H., Jerabek, L. and Weissman, I. L. (1994). Rapid and sustained hematopoietic recovery in lethally irradiated mice transplanted with purified Thy-1.1 $1^{\text {lo }} \mathrm{Lin}^{-} \mathrm{Sca}-1^{+}$hematopoietic stem cells. Blood 83, 3758-79.

Uchida, N. and Weissman, I. L. (1992). Searching for hematopoietic stem cells: evidence that Thy-1.1 ${ }^{\text {lo }} \mathrm{Lin}^{-} \mathrm{Sca}-1^{+}$cells are the only stem cells in C57BL/Ka-Thy-1.1 bone marrow. J Exp Med 175, 175-84.

Wu, L., Li, C.-L. and Shortman, K. (1996). Thymic dendritic cell precursors: relationship to the $\mathrm{T}$ lymphocyte lineage and phenotype of the dendritic cell progeny. J. Exp. Med. 184, 903-911.

(Accepted 6 March 1997) 